University of Nebraska - Lincoln

DigitalCommons@University of Nebraska - Lincoln

$1-23-2017$

\title{
Diet Composition of Age-0 Fishes in Created Habitats of the Lower Missouri River
}

Trevor A. Starks

James M. Long

Follow this and additional works at: https://digitalcommons.unl.edu/usgsstaffpub

Part of the Geology Commons, Oceanography and Atmospheric Sciences and Meteorology Commons, Other Earth Sciences Commons, and the Other Environmental Sciences Commons

This Article is brought to you for free and open access by the US Geological Survey at DigitalCommons@University of Nebraska - Lincoln. It has been accepted for inclusion in USGS Staff -- Published Research by an authorized administrator of DigitalCommons@University of Nebraska - Lincoln. 


\title{
Diet Composition of Age-0 Fishes in Created Habitats of the Lower Missouri River
}

\author{
TREVOR A. STARKS ${ }^{1}$ \\ Department of Natural Resources Ecology and Management, Oklahoma State University, Stillwater 74078
}

AND

JAMES M. LONG

U.S. Geological Survey, Oklahoma Cooperative Fish and Wildlife Research Unit, Department of Natural Resources Ecology and Management, Oklahoma State University, Stillwater 74078

\begin{abstract}
Aвstract.-Channelization of the Missouri River has greatly reduced the availability of shallow water habitats used by many larval and juvenile fishes and contributed to imperilment of floodplain-dependent biota. Creation of small side channels, or chutes, is being used to restore shallow water habitat and reverse negative environmental effects associated with channelization. In the summer of 2012, the U.S. Army Corps of Engineers collected early life stages of fishes from constructed chutes and nearby unrestored shallow habitats at six sites on the Missouri River between Rulo, Nebraska and St. Louis, Missouri. We compared the diets of two abundant species of fishes to test the hypothesis that created shallow chutes provided better foraging habitat for early life stages than nearby unrestored shallow habitats. Graphical analysis of feeding patterns of freshwater drum indicated specialization on chironomid larvae, which were consumed in greater numbers in unrestored mainstem reaches compared to chutes. Hiodon spp. were more generalist feeders with no differences in prey use between habitat types. Significantly greater numbers of individuals with empty stomachs were observed in chute shallow-water habitats, indicating poor foraging habitat. For these two species, constructed chute shallow-water habitat does not appear to provide the hypothesized benefits of higher quality foraging habitat.
\end{abstract}

\section{INTRODUCTION}

Degradation of freshwater habitats has prompted several large-scale restoration projects aimed at recovering lost ecosystem structure and function (Roni, 2005; Bernhardt et al., 2007). Restoration projects in large rivers have often been aimed at recovering losses of habitat complexity, biodiversity, and dynamic ecological processes at the river floodplain interface, which represents a species-rich environment that drives productivity and energy exchange at multiple trophic levels (Junk et al., 1989; Ward et al., 1999). Since 2003 there has been a large effort to construct shallow-water habitats ( $\mathrm{SWH}$ ) in the lower Missouri River that were lost during channelization for barge navigation (USFWS, 2003). However, difficulties with post monitoring make gauging the relative "success" of restoration problematic (Roni et al., 2005). A multitude of restoration metrics encompassing abiotic and biotic characteristics exist (Pess et al., 2005) and the responses by each may vary considerably.

Constructed SWH chutes in the lower Missouri River support more species of juvenile fishes than adjacent mainstem habitats, although there is no difference in effective number of species (Jost, 2006) between these habitats (Starks et al., 2015). Trophic responses by individual fish species may provide another means to assess the effectiveness of chute

\footnotetext{
${ }^{1}$ Present address: Oklahoma Department of Wildlife Conservation, $9097 \mathrm{~N}$ 34th St W, Porter, Oklahoma 74454; e-mail: tstarks1990@gmail.com
} 
construction on fishes that rely on the natural environments of the river. Analysis of the diets of fishes collected from different habitat types is one method for assessing responses to these restoration activities (Jud et al., 2011; Jordan and Arrington, 2014). This approach helps identify predator-prey relationships, trophic linkages, and other aspects of ecosystem function (Jordan and Arrington, 2014).

In the current study, we assessed diet metrics of age-0 (those individuals born within the last year) freshwater drum (Aplodinotus grunniens [Rafinesque]) and goldeye and mooneye (Hiodon alosoides [Rafinesque], Hiodon tergisus [Lesueur]) to determine trophic responses by fishes to creation of chute shallow-water habitats on the lower Missouri River. We focused on these species because they were abundant in both habitats throughout the river (Starks $\mathrm{et} \mathrm{al.}$, 2015) and to increase our understanding of the dietary needs of the early life stages of these fishes. Furthermore, there is a paucity of information on prey use by these two species at early life-history stages and results from this study would help fill this knowledge gap. Freshwater drum spawn in open water where buoyant eggs float for 1 to $2 \mathrm{~d}$ before hatching (Daiber, 1953). Diet studies of age-0 freshwater drum have been limited to lakes and reservoirs, where they have been described as consuming cladocerans, chironomid larvae, mayfly larvae, and occasionally larvae of other fishes (Swedburg and Walburg, 1970; Clark and Pearson, 1979; Bur, 1982). Both goldeye and mooneye are thought to spawn at midwater depths where semi-buoyant eggs and newly hatched larvae float freely (Battle and Sprules, 1960). Age-0 goldeye primarily consumed calanoid copepods and cladocerans in the Peace-Athabasca Delta, Alberta, Canada (Donald and Kooyman, 1976). Because feeding patterns can be attributed to habitat quality (e.g., prey availability or habitat heterogeneity; Tews et al., 2004), we sought to quantify prey richness, numbers of empty stomachs, and proportional prey use by these two commonly abundant fish species in chute and mainstem habitats in the lower Missouri River.

\section{Materials AND Methods}

SAMPLE COLLECTION

Age-0 freshwater drum, goldeye, and mooneye were collected by the U.S. Army Corps of Engineers (USACE) from early May to late July in 2012 at six sites in the Missouri River spanning the state of Missouri from Holt County (rkm 807) to St. Louis (rkm 17; Fig. 1). Each site consisted of paired mainstem and created chute SWH. Four chute habitats were constructed by the USACE (Rush Bottoms, 40.089633, -95.405367; Worthwine, 39.855141, -94.935116: Jameson, 39.085196, -92.923878; and Overton, 38.962589, -92.566414) whereas two were formed naturally (Lisbon, 39.113836, -92.930617 and Littles, 38.858144, -90.258695). However, all chutes were fitted with control structures at the upstream and downstream ends to maintain connection with the mainstem, which made them all "constructed" to varying degrees.

Paired sites were sampled bimonthly from May to July using dual bow-mounted ichthyoplankton nets $(750 \mu \mathrm{m}$ mesh, $750 \mathrm{~mm}$ diameter $)$ and a benthic sled $(750 \mu \mathrm{m}$ mesh, $750 \mathrm{~mm}$ diameter; Yocum and Tesar, 1980), each fitted with General Oceanics (General Oceanics Inc., Miami, Florida) model 2030R mechanical flow meters. Nets were deployed stationary or pushed through areas that met the standard for $\mathrm{SWH}$ (depth $<1.5 \mathrm{~m}$ and current velocity $<0.6 \mathrm{~m} / \mathrm{s}$; USFWS 2000, 2003) until a minimum volume of $500 \mathrm{~m}^{3}$ was sampled. The order in which chute or mainstem habitat was sampled at a given site was haphazardly chosen. Samples were preserved in $70 \%$ ethanol and identified using the larval fish key developed by Auer (1982). Goldeye (Hiodon alosoides) and mooneye (Hiodon tergisus) 


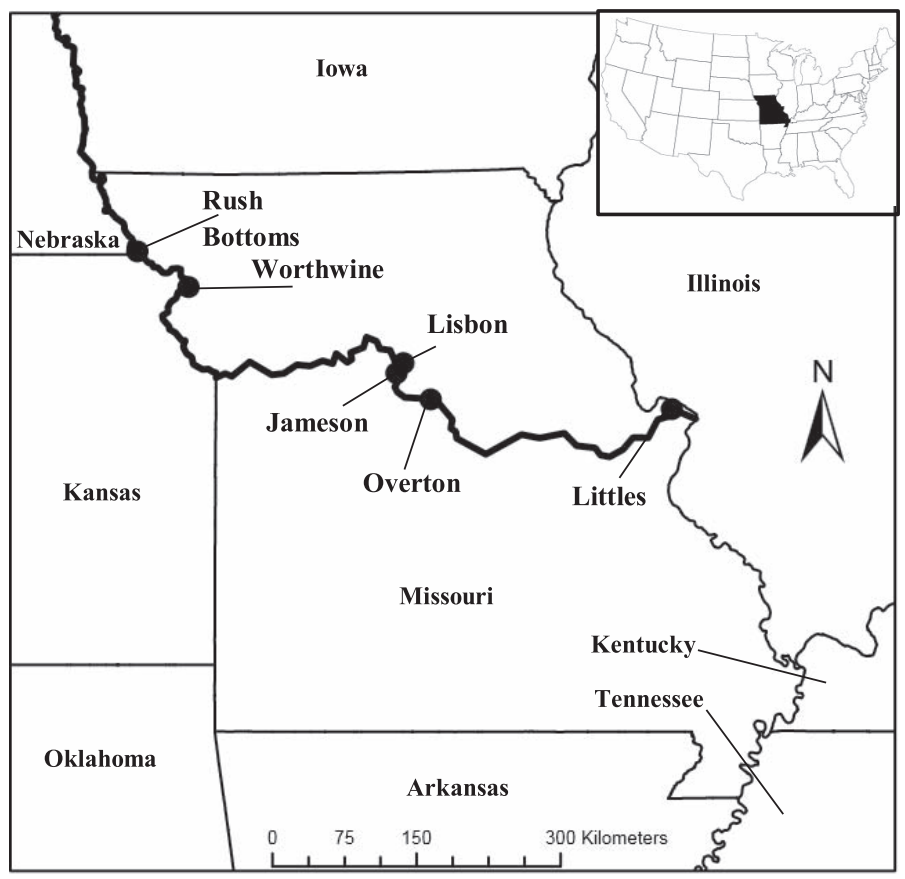

Fig. 1.-Paired chute and mainstem sites on the lower Missouri River sampled where juvenile freshwater drum and Hiodon spp. were captured in 2012 for prey use analysis

were grouped together as Hidon spp. because they could not be reliably identified to species at these early life stages, although they were most likely to be goldeye (Pflieger, 1997).

Juvenile fishes were measured for total length $(\mathrm{mm})$ and dissected to remove entire digestive tracts. Specimens that had not begun exogenous feeding (full or partial sac yolk) were not included in analysis, which resulted in 21 Hiodon spp. being excluded. Items found in the digestive tract were removed, quantified, and identified to the lowest practical taxonomic unit using the aquatic insect key developed by Merritt et al. (1996). Prey items that made up less than $1 \%$ of all diet items were grouped into a "rare" prey category and analyzed as a single prey type.

\section{STATISTICAL ANALYSIS}

Prey richness, number of empty stomachs, and proportion of each prey type consumed were quantified and analyzed for each group separately (freshwater drum and Hiodon spp.) to assess differences in habitat types. Paired $t$-tests were used to determine size differences of each species between habitat type.

Feeding patterns for each species were assessed using a graphical method to characterize feeding strategy (specialization vs. generalization), relative prey importance (rare or dominant), and niche variation (within or between individual variation; Costello, 1990; Amundsen et al., 1996). The modified graphical method by Amundsen et al. (1996) was used by plotting prey specific abundance $\left(P_{i}\right)$ against frequency of occurrence $\left(O_{i}\right)$. Prey specific abundance was calculated as $P_{i}=\left(\sum ; S_{i} / S_{t i}\right)$ where $P_{i}$ represents prey specific abundance of 
TABLE 1.-Mean total length $(\mathrm{mm})$ of freshwater drum and Hiodon spp. collected at each site and habitat type (chute and mainstem shallow water habitat) in the summer of 2012. Parentheses denote standard deviation

\begin{tabular}{lccccc}
\hline \hline \multirow{2}{*}{\multicolumn{1}{c}{ Site }} & \multicolumn{2}{c}{ Freshwater drum } & & \multicolumn{2}{c}{ Hiodon spp. } \\
\cline { 2 - 3 } & Chute SWH & Mainstem SWH & & Chute SWH & Mainstem SWH \\
\hline Rush Bottoms & $7.5(2.2)$ & $7.2(2.6)$ & & NA & NA \\
Worthwine & $6.2(1.6)$ & $8.4(1.9)$ & & $9.3(2.3)$ & NA \\
Lisbon & $8.2(3.4)$ & $6.9(3.4)$ & & $11.4(2.2)$ & $11.1(0.8)$ \\
Jameson & $5.3(2.3)$ & $4.6(0.8)$ & & $11.7(2.3)$ & $12.0(0.7)$ \\
Overton & $4.6(0.6)$ & $4.8(1.6)$ & & $15.2(3.8)$ & $12.2(2.2)$ \\
Littles & $4.9(0.8)$ & $5.0(0.8)$ & & $18.1(1.8)$ & $19.1(7.8)$ \\
\hline
\end{tabular}

prey $i, S_{i}$ is the abundance of prey $i$, in diets, and $S_{t i}$ is the total abundance of prey in predators that contain prey $i$. Frequency of occurrence $\left(O_{i}\right)$ was calculated by dividing the number of fish containing prey $i$ by the total number of conspecifics with food in their stomachs (Chipps and Garvey, 2007). Both metrics were calculated from all specimens collected from each habitat type for each species. Differences in numbers of empty stomachs between habitat types for each species were assessed using contingency tables. These analyses were performed using the "vegan" package (Oksanen et al., 2005) in Program R 3.0.2 (R Core Team, 2013) and results were considered significant at $\mathrm{P}<0.05$.

Differences in the proportions of each prey consumed by habitat and prey type were assessed using the generalized linear mixed-model procedure for each species (PROC GLIMMIX, SAS, 2014). These models contained the effects of habitat type (chute or mainstem), prey, and the interaction between habitat type and prey type. These models used a logit link and a binary distribution (prey type eaten $=1$, prey type not eaten $=0$ ) with site (Littles, Lisbon, Rush Bottoms, etc.) as a random effect. Subsequent testing of main effect differences in significant interaction terms were assessed using a SLICE statement within the generalized linear mixed-model procedure (SAS, 2014) and all results were considered significant at $\mathrm{P}<0.05$.

\section{RESUlts}

A total of 350 freshwater drum and 145 Hiodon spp. were collected in constructed chute SWH compared to 262 freshwater drum and 78 Hiodon spp. in mainstem SWH. In chutes drum and Hiodon spp. composed $6 \%$ and $2.6 \%$ of total catch, whereas in mainstem they composed $12.5 \%$ and $3.7 \%$, respectively. Freshwater drum total lengths ranged from $3 \mathrm{~mm}$ to $18 \mathrm{~mm}$, while Hiodon total lengths ranged from $4 \mathrm{~mm}$ to $38 \mathrm{~mm}$. Mean total length of fishes did not differ between habitat types (freshwater drum, paired- $t(16)=0.33, \mathrm{P}=0.79$; Hiodon spp., paired- $t(5)=0.97, \mathrm{P}=0.38)$, although Hiodon spp. (12.5 mm TL) were roughly twice as large as freshwater drum (5.7 mm TL; Table 1).

Most freshwater drum (82\%) and Hiodon spp. (87\%) had food in their stomachs. The number of empty stomachs was significantly greater in chute $\mathrm{SWH}$ for freshwater drum (contingency analysis, $\chi^{2}=54.99, \mathrm{P}=0.03$ ) but not Hiodon spp (contingency analysis, $\chi^{2}=$ $1.62, \mathrm{P}=0.20$ ). In chute habitat 63 freshwater drum and 20 Hiodon spp. had empty stomachs, whereas 30 freshwater drum and six Hiodon spp. collected in mainstem habitat had empty stomachs. 
TABLE 2.-Frequency of occurrence of prey types in age-0 freshwater drum and Hiodon spp. collected from created chute and nearby mainstem habitats in the lower Missouri River in the summer of 2012. Sample sizes are in parentheses. NA indicates prey item was not consumed by that species

\begin{tabular}{|c|c|c|c|c|}
\hline \multirow[b]{2}{*}{ Prey type } & \multicolumn{2}{|c|}{ Freshwater drum } & \multicolumn{2}{|c|}{ Hiodon spp. } \\
\hline & $\begin{array}{l}\text { Chute SWH } \\
(\mathrm{n}=287)\end{array}$ & $\begin{array}{l}\text { Mainstem SWH } \\
\quad(\mathrm{n}=232)\end{array}$ & $\begin{array}{l}\text { Chute SWH } \\
(\mathrm{n}=130)\end{array}$ & $\begin{array}{c}\text { Mainstem SWH } \\
\quad(\mathrm{n}=72)\end{array}$ \\
\hline Diptera larvae & $30.4 \%$ & $35.7 \%$ & $27.0 \%$ & $11.0 \%$ \\
\hline Diptera pupae & $10.2 \%$ & $6.3 \%$ & $30.3 \%$ & $11.8 \%$ \\
\hline Trichoptera larvae & $5.1 \%$ & $5.1 \%$ & $6.4 \%$ & $4.6 \%$ \\
\hline Copepoda & $0.7 \%$ & $2.5 \%$ & $0.2 \%$ & $0.4 \%$ \\
\hline Ephemeroptera larvae & $1.1 \%$ & $1.9 \%$ & $3.9 \%$ & $1.1 \%$ \\
\hline Cladocera & $0.6 \%$ & NA & $0.2 \%$ & $0.4 \%$ \\
\hline Amphipoda & $0.4 \%$ & NA & NA & NA \\
\hline Odonata larvae & NA & $0.1 \%$ & $1.1 \%$ & $0.6 \%$ \\
\hline Coleoptera larvae & NA & NA & $0.4 \%$ & $0.2 \%$ \\
\hline Terrestrial invertebrates & NA & NA & $0.2 \%$ & $0.4 \%$ \\
\hline Hemiptera insects & NA & NA & $0.2 \%$ & NA \\
\hline Ostracoda & NA & NA & NA & $0.2 \%$ \\
\hline Plecoptera larvae & NA & NA & $0.2 \%$ & NA \\
\hline
\end{tabular}

Over 13 prey types were found in dissected digestive tracts. Eight prey types made up less than $1 \%$ of total prey consumed in each species and were treated as one prey category ("rare prey") for analysis (Table 2). Prey types that contributed at least $1 \%$ of the diet of freshwater drum included Diptera larvae, Diptera pupae, Trichoptera larvae, copepods, and Ephemeroptera larvae. Prey types that contributed at least 1\% of the diet of Hiodon spp. were Diptera larvae, Diptera pupae, Trichoptera larvae, Ephemeroptera larvae, and Odonata larvae. Rare prey types included Plecoptera larvae, amphipods, Coleopteran larvae, Hemipteran larvae, ostracods, and two terrestrial invertebrates. Use of specific prey types differed by habitat type for freshwater drum $\left(\mathrm{F}_{5,3061}=3.29, \mathrm{P}<0.01\right)$ but not Hiodon spp. $\left(\mathrm{F}_{5}, 1155=0.67, \mathrm{P}=0.65\right)$. Of the prey consumed by freshwater drum, Diptera larvae were consumed more often in mainstem SWH than chute SWH (Fig. 2), whereas all comparisons for Hiodon spp. were not significantly different (Fig. 3). Graphical analysis indicates that freshwater drum specialized on Diptera larvae, which were also the dominant prey found in guts overall (Fig. 4). Graphs for Hiodon spp. indicate some specialization $\left(O_{i}=0.67, P_{i}=\right.$ 0.53 ) on Diptera pupae and Diptera larvae, whereas all other prey items were less consumed (Fig. 5).

\section{DisCUSSION}

Fishes, especially during their early life stages, are important indicators of the ecological integrity of river because they are responsive to changes in flow regime, water quality, habitat composition, and prey availability (Karr, 1991; Schiemer, 2003). In the current study, few differences in prey use by age-0 freshwater drum and Hiodon spp. were found between habitat types. However, the number of freshwater drum without food items in their stomachs found in chute habitats could indicate differences in habitat quality, with number of empty stomachs indicating relatively lower productivity levels (Knowlton and Jones, 2000; Bunn et al., 2003; O'Neill and Thorp, 2011). The proportion of empty stomachs for invertivores is 


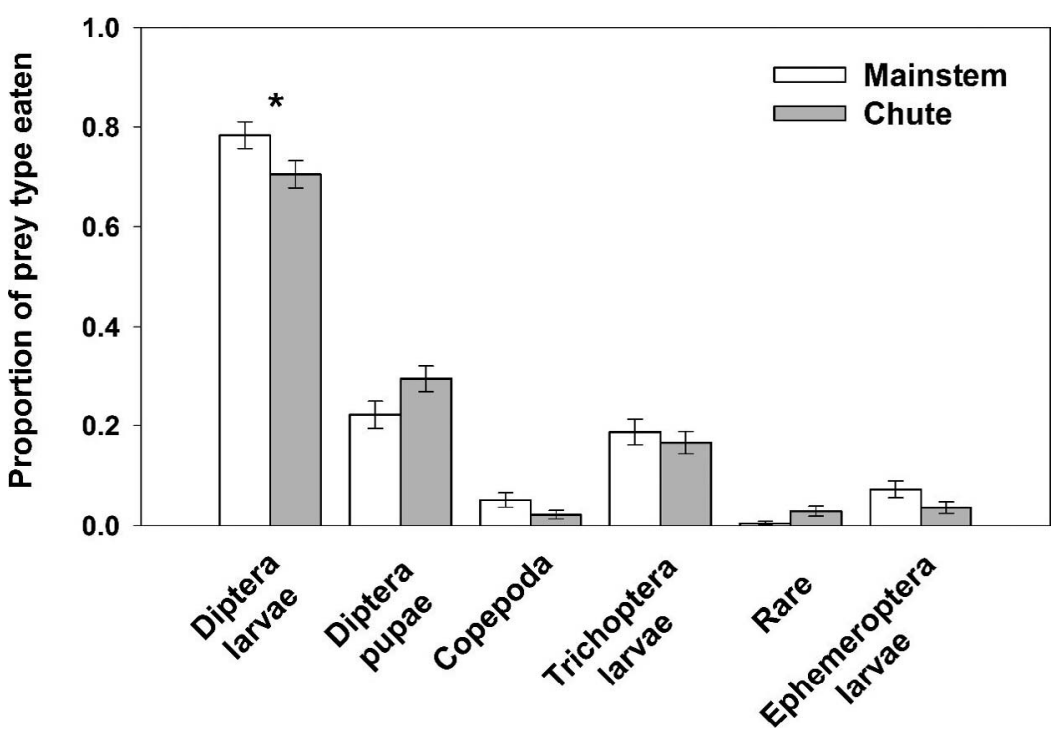

FIg. 2.-Proportions of each individual prey type consumed by larval freshwater drum caught in created chute and adjacent mainstem habitats in the summer of 2012. Error bars represent \pm 1 standard error. * Indicates a significant difference between mainstem and chute habitats for the prey type

considered "high" at about 10\% (Arrington et al., 2003) and 18\% of freshwater drum stomachs were empty in chute habitats (compared to $13 \%$ in mainstem habitats). However, these effects are also dependent on site-specific factors. For instance the frequency and duration of flood pulses have very strong influences on the timing of emergence and

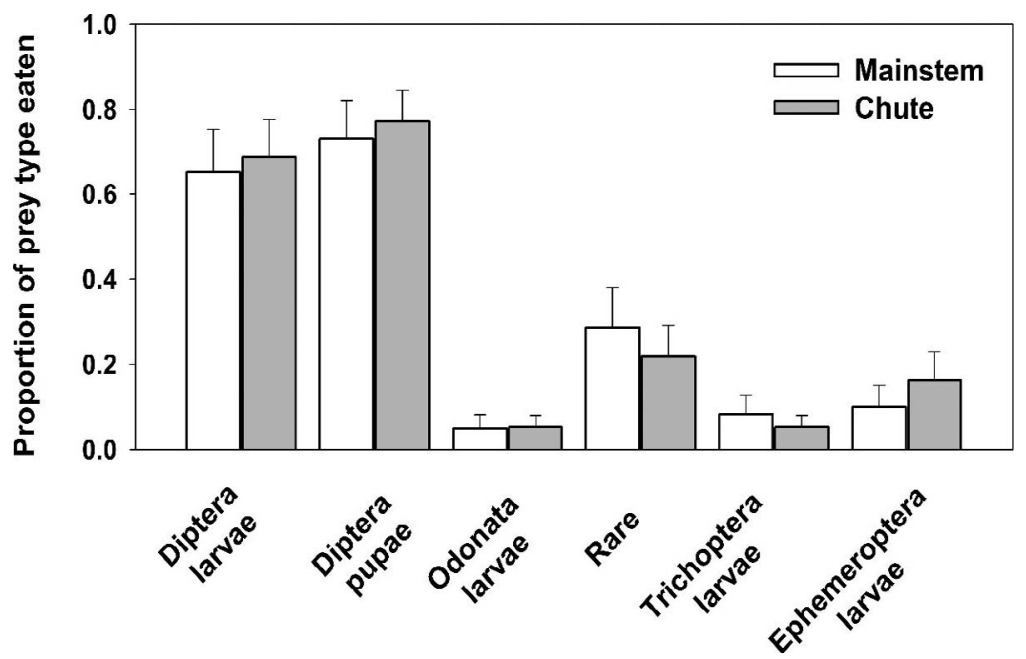

FIg. 3.-Proportions of each individual prey type consumed by larval Hiodon spp. caught in created chute and adjacent mainstem habitats in the summer of 2012. (Error bars represent $\pm 1 \mathrm{SE}$ ) 


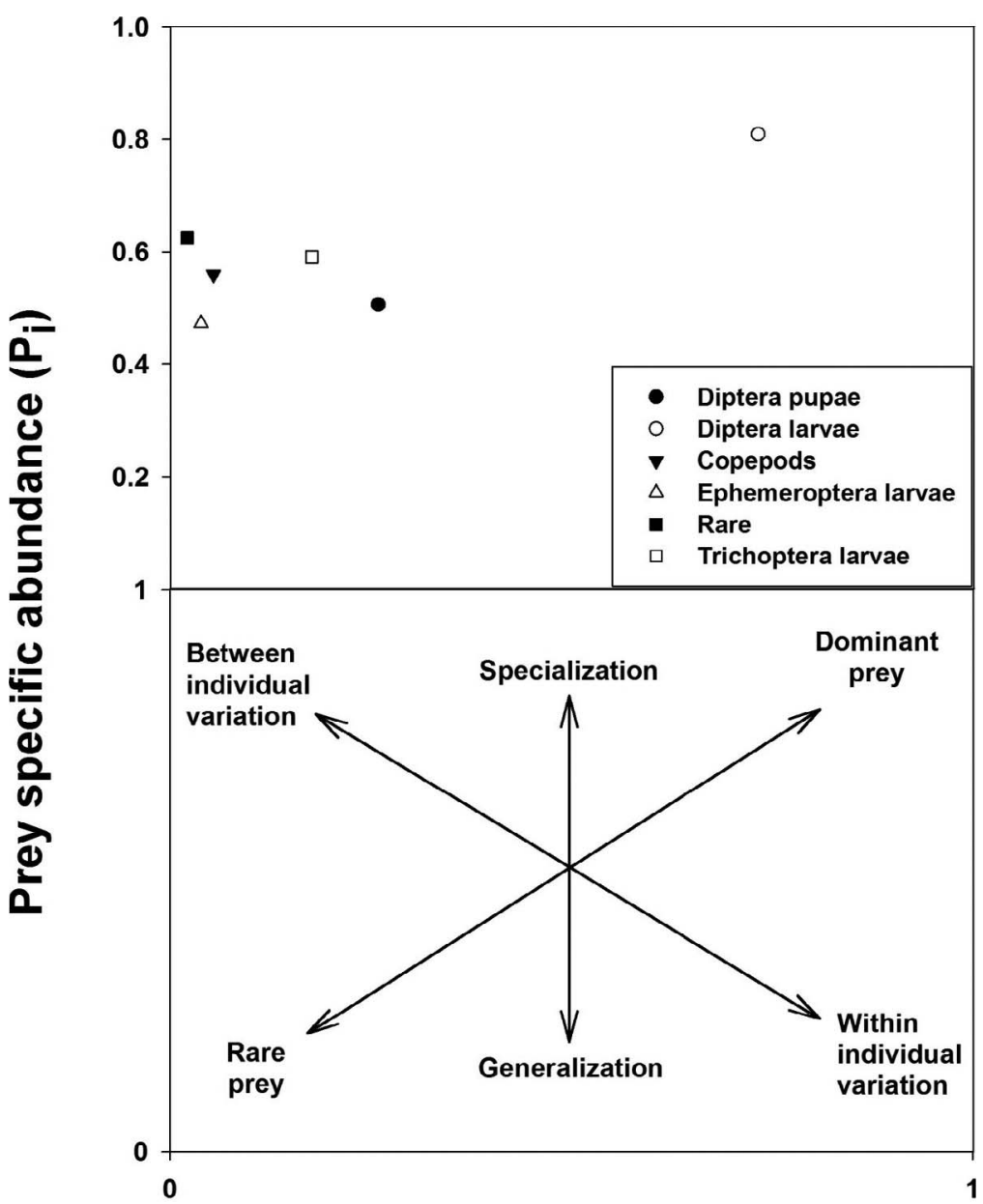

Frequency of occurence $\left(\mathrm{O}_{\mathbf{i}}\right)$

Fig. 4.-Amundsen index graph (along with key) indicating feeding strategy, prey importance, and niche width contribution or prey categories for freshwater drum sampled from the lower Missouri River in the summer of 2012

abundance of many aquatic invertebrate species that are important food sources for age- 0 fishes (Boulton and Lloyd, 1992; Lemke et al., 2003). The Lisbon and Overton chute SWH sites in particular were not connected with the mainstem Missouri River during periods of low flow in the summer of 2012, creating lentic conditions (Gosch et al., 2015). This reduced flow likely affected the resident invertebrate assemblage and increased competition among fishes for limited food resources (Garvey and Stein, 1998; Gosch et al., 2014). In the current study, $32 \%$ of freshwater drum and $55 \%$ of Hiodon spp. with empty stomachs came from Lisbon and Overton chutes alone. 


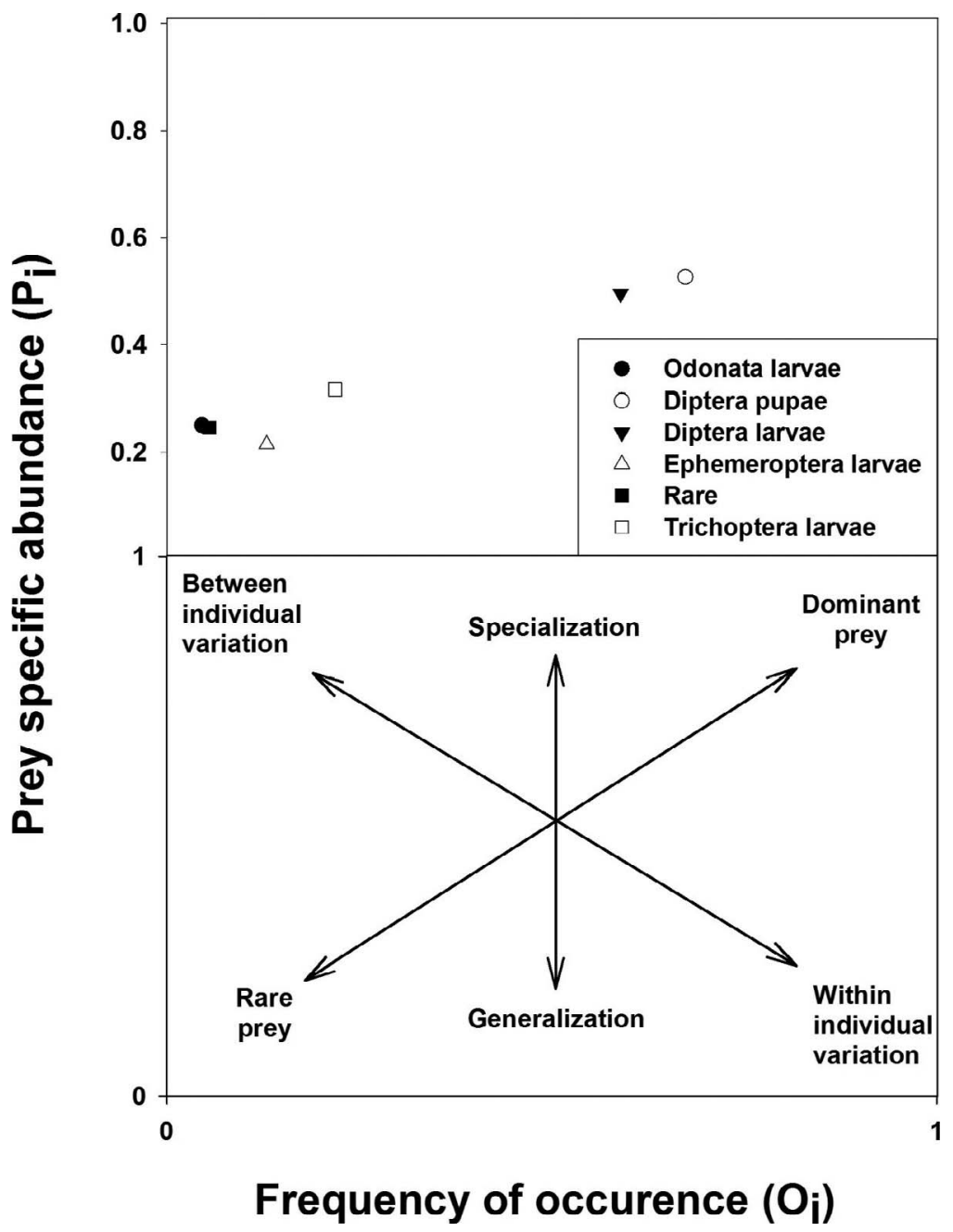

FIG. 5.-Amundsen index graph (along with key) indicating feeding strategy, prey importance, and niche width contribution or prey categories for Hiodon spp. sampled from the lower Missouri River in the summer of 2012

The higher proportion of Diptera larvae consumed by freshwater drum in mainstem $\mathrm{SWH}$ is likely linked with hydrologic conditions. Significant differences in macroinvertebrate community structures were found between lentic and lotic habitat types in the lower Missouri River (Sampson and Hall, 2011). Given that Diptera larvae, predominately chironomid larvae, tend to numerically dominate invertebrate communities in newly inundated $(<1 \mathrm{mo})$ lotic habitats, one would expect higher abundances of this prey source in mainstem SWHs as they maintain greater hydrological connection than some chutes (Galat et al., 1998; Gosch et al., 2014). From our findings it appears freshwater drum actively select for chironomid larvae, whereas Hiodon spp. were more opportunistic feeders. 
Additional research on these feeding relationships could help gauge predator-prey dynamics in created habitats, as well as indicate if SWHs are providing greater abundances of prey.

In conclusion created chute SWH does not appear to provide better quality foraging habitats than unrestored mainstem habitats for age- 0 freshwater drum, goldeye, and mooneye. The prevalence of specimens with empty stomachs in chute habitats may even point to a lack of foraging opportunities for these two species; however, the effect of hydrology on habitat structure and prey availability needs further investigation. Of the few studies done on these species, the habitat type in question seems to be the overall driving factor for foraging patterns. Habitat type seems to be a driving factor for foraging patterns of the age-0 fishes we studied, although more research is needed to gain a more holistic perspective of how habitat characteristics structure juvenile fish dynamics.

Acknowledgments. - Financial support for this publication was provided by the U.S. Army Corps of Engineers and the U.S. Geological Survey through Cooperative Agreement G12AC20430. We thank A. George for constructive comments that improved the paper. This study was performed under the auspices of a protocol approved by the U.S. Army Corps of Engineers. The Oklahoma Cooperative Fish and Wildlife Research Unit is supported by Oklahoma State University, Oklahoma Department of Wildlife Conservation, U.S. Geological Survey, U.S. Fish and Wildlife Service, and Wildlife Management Institute. Any use of trade, firm, or product names is for descriptive purposes only and does not imply endorsement by the U.S. Government.

\section{Literature Cited}

Amundsen, P. A., H. M. Gabler, and F. J. Staldvik. 1996. A new graphical analysis of feeding strategy from stomach contents data - modification of the Costello (1990) method. J. Fish Biol., 48:607-614. doi 10.1111/j.1095-8649.1996.tb01455.x

Arrington, D. A., K. O. Winemiller, W. F. Loftus, and S. Akin. 2002. How often do fishes "run on empty?" Ecology, 83:2145-2151. doi 10.2307?3072046

Auer, N. A. 1982. Identification of larval fishes of the Great Lakes basin with emphasis on the Lake Michigan drainage, p. 1-744. Great Lakes Fishery Commission, Ann Arbor, Michigan.

Battle, H. J. And W. M. Sprules. 1960. A description of the semi-buoyant eggs and early developmental stages of the goldeye, Hiodon alosoides (Rafinesque). J. Fish. Res. Board Can., 17:245-266. doi 10. $1139 / \mathrm{f} 60-020$

Bernhardt, E. S., E. B. Sudduth, M. A. Palmer, J. D. Allan, J. L. Meyer, G. Alexander, J. Follastad-Shah, B. Hassett, R. Jenkinson, R. Lave, J. Rumps, and L. Pagano. 2007. Restoring rivers one reach at a time: results from a survey of U.S. river restoration practitioners. Restor. Ecol., 15:482-493. doi 10.1111/j.1526-100X.2007.00244.x

Boulton, A. J. AND L. N. LLoyd. 1992. Flooding frequency and invertebrate emergence from dry floodplain sediments of the River Murray, Australia. Regul. River., 7:137-151. doi 10.1002/rrr. 3450070203

Bunn, S. W., P. M. Davies, And M. Winning. 2003. Sources of organic carbon supporting the food web of an arid zone floodplain river. Freshwater Biol., 48:619-635. doi 10.1046/j.1365-2427.2003.01031.x

Bur, M. T. 1982. Food of freshwater drum in western Lake Erie. J. Great Lakes Res., 8:672-675. doi 10. 1016/S0380-1330(82)72007-6

Chipps, S. R. And J. E. Garvey. 2007. Assessment of diets and feeding patterns, p. 473-514 In: C. S. Guy and M. L. Brown (eds.). Analysis and interpretation of freshwater fisheries data. American Fisheries Society, Bethesda, Maryland.

Clark, A. L. and D. W. Pearson. 1979. Early piscivory in larvae of freshwater drum, Aplodinotus grunniens, p. 32-59 In: R.W. Wallus and C.W. Voightlander (eds.). Proceeding of the 2nd Annual Larval Fish Workshop. TVA, Norris, Tennessee. 
Costello, M. J. 1990. Predator feeding strategy and prey importance: a new graphical analysis. J. Fish Biol. 36:261-263. doi 10.1111/j.1095-8649.1990.tb05601.x

Donald, D. B., AND A. H. Kooyman. 1976. Food, feeding habits and growth of goldeye, Hiodon alosoides (Rafinesque), in water of the Peace-Athabasca Delta. Can. J. Zoolog., 55:1038-1047. doi 10381047, 10.1139/z77-132

Galat D. L., L. H. Fredrickson, D. D. Humburg, K. J. Bataille, J. R. Bodie, J. Dohrenwned, G. T. Gelwicks, J. E. Havel, D. L. Helmers, J. B. Hooker, J. R. Jones, M. F. Knowlton, J. Kubisiak, J. Mazourek, A. C. Mccolpin, R. B. Renken, and R. D. Semlitsch. 1998. Flooding to restore connectivity of regulated, large-river wetlands. BioScience, 48:721-733. doi 10.2307/1313335

Garvey, J. E. And R. A. Stein. 1998. Competition between larval fishes in reservoirs: the role of relative timing of appearance. T. Am. Fish. Soc., 127:1021-1039. doi 10.1577/1548-8659(1998) 127 $<1021$ :CBLFIR $>2.0 . \mathrm{CO} ; 2$

Gosch, N. J. C., M. L. Miller, A. R. Dzialowski, D. M. Morris, T. R. Gemeinhardt, and J. L. Bonneau. 2014. Assessment of Missouri River floodplain invertebrates during historic inundation: implications for river restoration. Knowl. Manag. of Aquat. Ec., 412:1-15. doi http://dx.doi.org/10.1051/ $\mathrm{kmae} / 2013087$

- - - T. R. Gemeinhardt, S. J. Sampson, And J. L. Bonneau. 2015. Age-0 sturgeon accessibility to constructed and modified chutes in the lower Missouri River. N. Am. J. Fish. Manage, 35:75-85. doi $10.1080 / 02755947.2014 .975300$

Jordan, F. And D. A. ARrington. 2014. Piscivore responses to enhancement of the channelized Kissimmee River, Florida, U.S.A. Restor. Ecol., 22:418-425. doi 10.1111/rec.12060

Jost, L. 2006. Entropy and diversity. Oikos, 113:363-375. doi 10.1111/j.2006.0030-1299.14714

Jud, Z. R., C. A. Layman, and J. M. Shenker. 2011. Diet of age-0 tarpon (Megalops atlanticus) in anthropogenically-modified and natural nursery habitats along the Indian River Lagoon, Florida. Environ. Biol. Fish., 90:223-233. doi 10.1007/s10641-010-9734-6

Junk, W. J., P. B. Bayley, and R. E. Sparks. 1989. The flood pulse concept in river-floodplain systems, p. 110-127 In: D.P. Dodge (ed.). Proceedings of the International Large River Symposium. Canadian Journal of Fisheries and Aquatic Science, Special Publication 106.

KARR, J. R. 1991. Biological integrity: a long neglected aspect of water resource management. Ecol. Appl., 1:66-84. doi http://dx.doi.org/10.2307/1941848

— AND E. W. Chu. 1999. Restoring life in running waters: better biological monitoring, p. 1-209. Island Press, Washington, D.C.

Knowlton, M. F. AND J. R. Jones. 2000. Seston, light, nutrients and chlorophyll in the lower Missouri River, 1994-1998. J. Freshwater Ecol., 15:283-297. doi 10.1080/02705060.2000.9663747

Lemke, A. M., J. A. Stoeckel, And M. A. Pegg. 2003. Utilization of the exotic cladoceran Daphnia lumholtzei by juvenile fishes in an Illinois River floodplain lake. J. Fish Biol., 62:938-954. doi 10.1046/j. 1095-8649.2003.00090.x

Merritt, R. W., K. W. Cummins, and M. B. Berg. 1996. An introduction to the aquatic insects of North America, p. 1-867. Kendall Hunt, Dubuque, Iowa.

Oksanen, J., R. Kindt, and R. B. O'Hara. 2005. Vegan: community ecology package version 1.6-9 (Accessed 01/2015).

O'Neill, B. J. And J. H. Thorp. 2011. Flow refugia for the zoobenthos of a sand-bed river: the role of physical-habitat complexity. J. N. Am. Benthol. Soc., 20:546-558. doi http://dx.doi.org/10.1899/ 10-083.1

Pess, G. R., S. A. Morley, J. L. Hall, and R. K. Timm. 2005. Monitoring floodplain restoration, p. 127-167 In: P.M. Roni (ed.). Monitoring stream and watershed restoration. American Fisheries Society, Bethesda, Maryland.

Pflieger, W. L. 1997. The fishes of Missouri. Missouri Department of Conservation, Jefferson City, Missouri.

R Core Team. 2013. R: A language and environment for statistical computing. R Foundation for Statistical Computing, Vienna, Austria. 
Roni, P. M., M.C. Liermann, C. Jordan, and E. A. Steel. 2005. Steps for designing a monitoring and evaluation program for aquatic restoration, p. 13-35 In: P.M. Roni (ed.). Monitoring stream and watershed restoration. American Fisheries Society, Bethesda, Maryland.

SAMPSON, S. J. AND J. R. Hall. 2011. Habitat assessment and monitoring program: macroinvertebrate community assessment of constructed backwaters and side channels of the channelized Missouri River, 2010, p. 26 In: Nebraska Game and Parks Commission, Lincoln, Nebraska.

SAS (Statistical Analysis Systems). 2014. SAS/STAT user's guide, version 9.3, SAS Institute, Cary, North Carolina.

Schiemer, F., H. Keckeis, and W. Kamler. 2003. The early life history stages of riverine fish: ecophysiological and environmental bottlenecks. Comp. Biochem. Phys. A, 133:439-449. doi 10. 1016/S1095-6433(02)00246-5

Starks, T. A., J. M. Long, and A. R. Dzialowski. 2015. Community structure of age-0 fishes in paired mainstem and created shallow-water habitats in the lower Missouri River. River Res. and Appl. doi: $10.1002 /$ rra.2891

Swedberg, D. V. and C. H. Walberg. 1970. Spawning and early life history of the freshwater drum in Lewis and Clark Lake, Missouri River. T. Am. Fish. Soc., 99:560-570.

Tews, J., U. Brose, V. Grimm, K. Tielborger, M.C. Wichmann, M. Schwager, and F. Jeltsch. 2004. Animal species diversity driven by habitat heterogeneity/diversity: the importance of keystone structures. J. Biogeogr., 31:79-92. doi 10.1046/j.0305-0270.2003.00994.x

U.S. Fish and Wildlife Service (USFWS). 2000. USFWS 2000 biological opinion on the operation of the Missouri River main stem reservoir system, operation and maintenance of the Missouri River bank stabilization and navigation project, and operation of the Kansas River reservoir system, p. 1-385. USFWS, Denver Colorado.

2003. Amendment to the 2000 biological opinion of the operation of the Missouri River main stem reservoir system, operation and maintenance of the Missouri River banks stabilization and navigation project and operation of the Kansas River reservoir system, p. 1-385. USFWS, Denver, Colorado.

Ward, J. V., K. Tockner, U. Uehlinger, and F. Malard. 2001. Understanding natural patterns and processes in river corridors as the basis for effective river restoration. Regul. River., 17:311-323. doi $10.1002 /$ rrr.646

Yocum, W.L. and F.J. Tesar. 1980. Sled for sampling benthic fish larvae. Prog. Fish Cult., 42:118-119. doi 10.1577/1548-8659(1980) 42[118:SFSBFL]2.0CO;2 